\title{
Analisis Kepuasan Konsumen Terhadap Kualitas Pelayanan Di Warung Steak On You Kota Baru Jambi
}

\author{
${ }^{1}$ Siti Nur Khoiria, ${ }^{2}$ Kasful Anwar US \\ 1-2 Jurusan Ekonomi Syariah, Fakultas Ekonomi dan Bisnis Islam, Universitas Islam Negeri Sulthan Thaha \\ Saifuddin Jambi
}

Article history

Received: 10-03-2021

Revised: 12-04-2021

Accepted: 03-052021

*Corresponding Author:

Siti Nur Khoiria,

Kafsul Anwar US,

Jurusan Ekonomi Syariah,

Fakultas Ekonomi dan

bisnis Islam,

Universitas Negeri Sulthan

Thaha Saifuddin Jambi

Email: stnknur1@gmail.co

$\underline{m}$

\begin{abstract}
Abstrak: Penelitian ini berfokus pada kualitas pelayanan berdasarkan kepuasan pelanggan terhadap Warung Steak On You di Kota Jambi. Tujuan penelitian ini mengetahui dan mengevaluasi tentang kepuasan konsumen terhadap pelayanan yang diberikan oleh Warung Steak On You sebagai tempat makan yang banyak digemari masyarakat Kota Jambi khususnya para remaja. Metode yang digunakan adalah metode Analisis Deskriptif Kualitatif dan metode ServQual. Metode ServQual ini terdiri dari penilaian terhadap beberapa dimensi yaitu: Reliability (Kehandalan), Responsiveness (Daya Tanggap), Assurance (Jaminan), Empathy (Empati) dan Tangible (Bukti Fisik). Penilaian dalam pengumpulan data dilakukan dengan observasi lingkungan sekitar Warung Steak On You dan wawancara langsung terhadap konsumen Warung Steak On You sebagai responden penelitiannya. Hasil yang diperoleh dalam penelitian ini adalah kualitas pelayanan yang diberikan memiliki pengaruh yang signifikan terhadap kepuasan konsumen. Hasil dari penelitian juga mendapatkan hasil bahwa para konsumen dinilai puas dengan pelayanan yang diberikan oleh Warung Steak On You. Hal ini dapat menjadi evaluasi tentang efektifitas kualitas pelayanan yang diberikan kepada konsumen.

Kata Kunci: Kepuasan Konsumen, Kualitas Pelayanan
\end{abstract}

\section{PENDAHULUAN}

Perkembangan perekonomian pada saat ini sangat mempengaruhi kehidupan masyarakat dalam menentukan kebutuhan yang mereka butuhkan. Pengaruh dari tingkat pendapatan seiring dengan meningkatnya pertumbuhan penduduk saat ini juga berpengaruh terhadap tingkat permintaan masyarakat. Dengan tingginya tingkat permintaan banyak dari perusahaan kecil sampai perusahaan besar berlomba-lomba dalam mempromosikan produk yang mereka hasilkan. Hal tersebut juga menjadikan kualitas pelayanan yang diberikan oleh penghasil produksi dalam memperoleh kepuasan pelanggan terhadap produk yang mereka tawarkan. Banyak dari produsen berlomba-lomba untuk menghasilkan produk ataupun kualitas yang baik sehingga mampu mempunyai keunggulan dalam bersaing dengan perusahaan lainnya. Sehingga nantinya jika konsumen merasa pelayanan yang diberikan sangat memuaskan mereka akan menjadi pelanggan terhadap produk atau jasa dari perusahaan tersebut. Kepuasan konsumen nantinya akan menciptakan keyakinan terhadap perusahaan tersebut dalam memberikan produk atau jasa yang berkualitas dan memuaskan. Jika nantinya kualitas yang diberikan oleh perusahaan sangat baik maka akan terciptanya sebuah kepuasan konsumen.

Selain itu dengan melakukan metode pemasaran. Pemasaran berusaha menciptakan dan melakukan pertukaran produk baik barang maupun jasa kepada konsumen pasar. Seiring dengan perkembangan saat ini persaingan menjadi sangat ketat yang membuat para jasa pemberi layanan harus memberikan kepuasan kepada konsumennya. Dalam memberikan kualitas pelayanan ini tentunya tanpa harus membedakan antara konsumen satu dengan konsumen lainnya. Sebagai seorang karyawan yang memberikan langsung pelayanannya 
kepada konsumen juga harus didasari oleh sikap penuh tanggung jawab dalam melakukan pekerjaannya. Artinya setiap pelayanan yang dia berikan setidaknya harus bisa memberikan tingkat kepuasan yang tidak megecewakan kepada konsumennya. Jika sudah memiliki rasa tanggung jawab dan disiplin dalam melakukan pekerjaannya maka akan memberikan kepuasan baik kepada konsumennya, pekerjaannya ataupun perusahaannya sendiri.

Sebuah usaha juga harus memberikan sebuah pelayanan yang jujur dan terus terang artinya apabila terdapat hambatan karena suatu masalah yang tidak dapat dielakkan hendaknya diberitahukan, sehingga orang tidak menunggu-nunggu sesuatu yang tidak menentu. Dengan pemberitahuan konsumen dapat mengerti dan akan menyesuaikan diri secara ikhlas tanpa emosi. Pada dasarnya setiap orang dapat memahami kesulitan dan masalah orang lain, kalau hal itu dikemukakan dengan terus terang. Jika beberapa hal tersebut dapat dijalankan dengan baik maka konsumen akan merasa puas dan dampak kepuasan konsumen terlihat pada:

1.Konsumen tidak akan memandang remeh dan berlaku sembarangan terhadap pelayanan yang diberikan.

2. Munculnya rasa bangga pada konsumen terhadap pelayanan yang diberikan oleh karyawan tersebut, sehingga nantinya bisa membawa dampak positif terhadap usaha mempertahankan citra karyawan yang tangguh, tanggap dan disiplin.

3. Meingkatkan gairah konsumen untuk berkunjung ke usaha tersebut lagi karena pelayanan yang diberikan mencapai tingkat kepuasan.

Warung Steak On You juga berfokus dalam memberikan pelayanan yang sebaik mungkin kepada para konsumennya. Apalagi pada saat ini seluruh provinsi yang ada di Indonesia sedang dilanda virus Covid-19 yang harus diwaspadai oleh seluruh masyrakat di Indonesia. Seluruh warga di himbau untuk tetap berada dirumah saja jikalau ingin keluar rumah harus tetap mentaati protocol kesehatan. Khususnya di cafe ataupun restoran yang diyakini menjadi tempat rawan penyebaran virus corona. Jika mengunjungi tempat-tempat itu, otomatis kita akan melepas masker untuk makan atau minum. Hal itulah yang membuat penularan Covid-19 lebih parah. Tetapi Warung Steak On You tetap menerapkan protocol kesehatan untuk mencegah terjadinya penyebaran rantai virus Covid-19. Sebelum virus Covid-19 Warung Steak On You ini sudah mempunyai tempat makan outdoor. Karna virus Covid-19 ini diyakini juga dapat meyebar jika kita makan atau minum di dalam tempat yang tertutup. Warung Steak On You juga sudah memberikan batas jarak pada tempat duduk para konsumennya, yang tadinya satu meja bisa 4 orang sekarang menjadi 2 orang saja. Sebelum masuk ke Warung Steak On You ini juga kita dihimbau untuk melakukan cuci tangan dan pengecekan suhu terlebih dahulu.

Warung Steak On You berorientasi pada kepuasan konsumen sehingga mampu bersaing di dunia usaha makanan. Perkembangan Warung Steak On You tidak terlepas dari upaya yang selalu dilakukan oleh pihak perusahaan untuk dapat memaksimumkan serta memberikan kepuasan bagi semua pelanggannya.

Tujuan yang ingin dicapai pada penelitian ini adalah untuk menganalisis kepuasan konsumen terhadap pengaruh kualitas pelayanan yang diberikan oleh Warung Steak On You.

\section{Landasan Teori}




\section{Pengertian Konsumen}

Istilah konsumen sering diartikan sebagai dua jenis konsumen yaitu; konsumen individu dan konsumen organisasi. Konsumen individu membeli barang dan jasa untuk digunakan sendiri. Misalnya membeli pakaian, sepatu, dan sabun. Konsurnen individu rnembeli barang dan jasa yang akan digunakan oleh anggota keluarga yang lain. Dalam konteks barang dan jasa yang dibeli kemudian digunakan langsung oleh individu dan sering disebut sebagai "pemakai akhir" atau "konsumen akhir". Jenis kedua adalah konsumen organisasi, yang meliputi organisasi bisnis, yayasan, lembaga sosial, kantor pemerintah, dan lembaga lainnya (sekolah, perguruan tinggi, rumah sakit). Semua jenis organisasi ini harus membeli produk peralatan dan jasa-jasa lainnya untuk menjalankan seluruh kegiatan organisasinya. Konsumen adalah setiap orang pemakai barang dan/atau jasa yang tersedia dalam masyarakat, baik bagi kepentingan diri sendiri, keluarga, orang lain, maupun makhluk hidup lain dan tidak untuk diperdagangkan. Konsumen dapat dikelompokkan yakni konsumen antara dan konsumen akhir. Konsumen antara adalah distributor, agen dan pengecer. Mereka membeli barang bukan untuk dipakai, melainkan untuk diperdagangkan. Sedangkan pengguna barang adalah konsumen akhir. Yang dimaksud konsumen akhir adalah konsumen akhir memperoleh barang atau jasa bukan untuk dijual kembali, melainkan untuk digunakan, baik bagi kepentingan dirinya sendiri, keluarga, orang lain dan makhluk hidup lain (Tatik Suryani, 2003).

\section{Kepuasan Konsumen}

Kepuasan konsumen merupakan salah satu indikator keberhasilan dari suatu usaha. Hal ini telah dipercaya secara umum karena dengan memuaskan konsumen maka organisasi dapat meningkatkan tingkat keuntungannya dan mendapatkan pangsa pasar yang lebih luas (Barsky, 1992, dalam Daryanto \& Setyobudi, 2014). Menurut Daryanto \& Setyobudi (2014), kepuasan konsumen merupakan suatu penilaian emosional dari konsumen setelah konsumen menggunakan suatu produk, dimana harapan dan kebutuhan konsumen yang menggunakannya terpenuhi.

\section{Kualitas Pelayanan}

Pelayanan adalah kunci keberhasilan dalam berbagai usaha pada kegiatan yang sifatnya jasa. Tingkat pelayanan merupakan suatu tingkat yang ditunjukkan oleh perusahaan atau instansi dalam menangangi orang-orang yang memerlukan pelayanan tersebut. Tjiptono dan Chandra (2005) mengemukakan bahwa konsep orientasi pelayanan lebih menekankan pada aspek praktik, kebijakan dan prosedur layanan pada sebuah organisasi, sehingga berdampak pada kepuasan konsumen (dalam Amir, 2012). Menurut Kotler (Subihaiani,2001) kualitas layanan merupakan suatu bentuk penilaian konsumen terhadap tingkat layanan yang dipersepsikan (Perceived service) dengan tingkat kepuasan konsumen yang diharapakan (expected Lokasi). Kualitas pelayanan terbagi kedalam lima dimensi yaitu reliability, responsiveness, assurance, empathy, tangibles.

a) Reliability (Kehandalan) yaitu kemampuan perusahaan untuk memberikan kepuasan konsumen yang dijanjikan secara akurat dan terpercaya.

b) Responsiveness (ketanggapan) yaitu suatu kemauan untuk membantu dan 
memberikan kepuasan konsumen yang cepat dan tepat kepada konsumen, dengan penyampaian informasi yang jelas.

c) Assurance (jaminan) yaitu pengetahuan, kesopanan, dan kemampuan para pegawai perusahaan untuk menumbuhkan rasa percaya para konsumen pada perusahaan.

d) Empathy (Empati) yaitu memberikan perhatian yang tulus dan bersifat pribadi yang diberikan kepada para konsumen dengan berupaya memahami keinginan konsumen.

e) Tangible (bukti fisik) yaitu kemampuan suatu perusahaan dalam menunjukan eksistensinya kepada pihak eksternal. Penampilan dan kemampuan saran dan prasarana fisik serta keadaan lingkungan sekitarnya adalah bukti nyata dari palayanan yang diberikan oleh pemberi jasa. Yang meliputi fasilitas fisik (gedung, gudang dan lain sebagainya), perlengkapan dan peralatan yang dipergunakan (teknologi) serta penampilan pegawainya.

\section{Penelitian Terdahulu}

Fandi (2013) melakukan penelitian tentang Analisis Kepuasan Konsumen Warung Steak And Shake Kota Wisata Batu. Tujuan penelitian ini untuk menganalisis faktor-faktor yang mempengaruhi kepuasan konsumen dan karakteristik Waroeng Steak di Kota Wisata Batu. Hasil analisis menunjukkan bahwa kepuasan pelanggan di Waroeng Steak and Shake Kota Wisata Batu dipengaruhi oleh 4 faktor yaitu kemudahan mendapatproduk, kebersihan fasilitas restoran dan bentuk produk. Karakteristik konsumen yang paling banyak datang atau paling dominan di Waroeng Steak and Shake adalah berjenis kelamin perempuan sebanyak $60 \%$ berusia 21-25 tahun (43\%) dengan tingkat pendidikan terakhir sarjana (S1) dan memiliki pendapatan sebesar Rp. 900.000 s/d < Rp. 1.800.000,- (39\%).

Putu Anggi Ranitaswari (2018) melakukan penelitian tentang Analisis Kepuasan Konsumen Terhadap Kualitas Produk Kopi dan Kualitas Pelayanan (Studi Kasus Di Geo Coffe). Tujuan dari penelitian ini adalah untuk menganalisis kepuasan konsumen terhadap kualitas produk dan pelayanan di Geo Coffe perlu dilakukan untuk mengidentifikasi faktorfaktor yang perlu diperhatikan dalam meningkatkan kualitas produk dan kualitas pelayanan. Hasil dari analisis ini yaitu kualitas produk dianggap penting diurutkan dari besar ke kecil: rasa kopi, aroma kopi, affertaste, konsistensi, kualitas pelayanan. Tingkat kinerja kualitas produk diurut berdasarkan 3 nilai tertinggi adalah sebagai berikut rasa kopi, keasaman rasa, aroma dan aroma kopi. Serta kepuasan konsumen terhadap kualitas produk tertinggi: unsur aroma kopi $(101,95 \%)$ dan tingkat penyesuainnya terendah: konsistensi rasa kopi setiap penyajian $(82,52 \%)$, untuk tingkat kepuasan konsumen terhadap kualitas pelayanan tertinggi: kecepatan dalam merespon keluhan 9120,34\%) tingkat kesesuaian terendah: pelayanan menangani konsumen sesuai kebutuhan $(80,05 \%)$.

\section{METODE PENELITIAN}

Penelitian ini dilaksanakan di Warung Steak On You yang terletak di daerah Kota Baru Jambi. Data yang dikumpulkan dalam penelitian ini merupakan data primer dengan melakuan observasi langsung ke lokasi, melalui wawancara dengan pihak manajer atau pihak yang mewakili restoran tersebut. Dan juga melakukan wawancara langsung terhadap konsumen Warung Steak On You. Populasi dalam penelitian ini adalah semua kalangan yang 
ada di Warung Steak On You Kota Baru Jambi. Teknik pengambilan sampel yang digunakan adalah sampling incidental yang merupakan teknik penentuan sampel berdasarkan kebetulan. Yaitu siapa saja yang secara kebetulan bertemu dengan peneliti dapat digunakan sebagai sampel bila dipandang orang yang kebetulan ditemui itu cocok sebagai sumber data.

Metode yang digunakan adalah metode deskriptif kualitatif. Penelitian deskriptif yaitu mengumpulkan data berdasarkan faktor- faktor yang menjadi pendukung terhadap objek penelitian, kemudian menganalisa faktor-faktor tersebut untuk dicari peranannya (Arikunto, 2010: 151). Penelitian kualitatif merupakan penelitian yang berhubungan dengan ide, persepsi, pendapat, kepercayaan orang yang akan diteliti dan kesemuanya tidak dapat di ukur dengan angka. Dalam penelitian ini, teori yang digunakan dalam penelitian tidak dipaksakan untuk memperoleh gambaran seutuhnya mengenai suatu hal menurut pandangan manusia yang telah diteliti (Sulistyo-Basuki, 2006:24). Metode pendekatan Deskriptif Kualitatif adalah metode pengolahan data dengan cara menganalisa faktor-faktor yang berkaitan dengan objek penelitian dengan penyajian data secara lebih mendalam terhadap objek penelitian.

Pengambilan sampel dilakukan dengan metode nonprobability sampling jenis sampling incidental, dengan jumlah populasi tidak diketahui dan jumlah sampel sebanyak 50 orang. Karena peneliti menggunakan proses wawancara langsung yang berupa pengumpulan katakata dari respondennya. Penelitian ini juga langsung mengobservasi sejauh mana tingkat kepuasan konsumen terhadap pelayanan yang diberikan. Mengapa peneliti menggunakan metode ini dikarenakan tidak setiap hari Warung Steak On You ramai dikunjungi pelanggan dan tidak semua pengunjung bisa untuk diwawancara. Dan hal ini juga mengacu pada penelitian terdahulu yang menggunakan metode ini pada jurnal sebelumnya. Metode ini juga mengacu pada referensi jurnal lain yang terdapat dalam judul ANALISIS KEPUASAN KONSUMEN TERHADAP LAYANAN SPA DENGAN SERVQUAL.

\section{HASIL DAN PEMBAHASAN}

Setelah melakukan wawancara sekaligus penyebaran kuisioner kepada beberapa konsumen Warung Steak On You Kota Baru Jambi selanjutnya peneliti melakukan penghitungan kuisioner dengan Metode Service Quality (SERVQUAL). Berdasarkan data jumlah penelitian seluruh pernyataan ada 50 sampel.

Tabel 1 (Jumlah Bobot)

\begin{tabular}{rll}
\hline $\begin{array}{c}\text { Jumlah } \\
\text { Bobot }\end{array}$ & Persepsi & Harapan \\
\hline 1 & Tidak Puas & Tidak Penting \\
2 & Cukup Puas & Cukup Penting \\
3 & Puas & Penting \\
4 & Sangat Puas & Sangat Penting \\
Rumus GAP: G= P-E & &
\end{tabular}

Ket: 
$\mathrm{G}=$ Kesenjangan

$\mathrm{P}=$ Persepsi Layanan

$\mathrm{E}=$ Harapan Layanan

Rumus untuk menghitung nilai persepsi pelayanan yang dirasakan oleh konsumen:

$\Sigma X i=(\Sigma T P \times 1)+(\Sigma C P \times 2)+(\Sigma P \times 3)+(\Sigma S P \times 4)$

Rumus untuk menghitung nilai harapan pelayanan yang dirasakan oleh konsumen:

$\Sigma Y i=(\Sigma T P \times 1)+(\Sigma C P \times 2)+(\Sigma P \times 3)+(\Sigma S P \times 4)$

Rumus Rata-Rata Nilai Persepsi Konsumen:

$\sum X \boldsymbol{X} \mathrm{Xi}^{-}=$

Rumus Rata-Rata Nilai HarapanKonsumen:

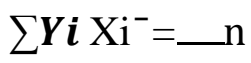

Tabel 2 Atribut Pertanyaan

\begin{tabular}{|c|c|c|c|}
\hline No & Variabel & & Atribut \\
\hline \multirow{5}{*}{1} & \multirow{5}{*}{$\begin{array}{l}\text { Kehandalan } \\
\text { (Reliability) }\end{array}$} & A1 & $\begin{array}{l}\text { Kecepatan karyawan dalam memberikan } \\
\text { daftar menu kepada konsumen }\end{array}$ \\
\hline & & A2 & $\begin{array}{l}\text { Karyawan memberikan pelayanan yang sama } \\
\text { dan konsisten setiap waktu }\end{array}$ \\
\hline & & A3 & $\begin{array}{l}\text { Estimasi waktu karyawan dalam menyajikan } \\
\text { makanan }\end{array}$ \\
\hline & & A4 & $\begin{array}{l}\text { Kecepatan dalam membersihkan meja makan } \\
\text { konsumen sebelumnya }\end{array}$ \\
\hline & & A5 & $\begin{array}{l}\text { Keandalan dalam menawarkan menu yang } \\
\text { enak dan murah meriah }\end{array}$ \\
\hline \multirow{5}{*}{2} & \multirow{5}{*}{$\begin{array}{l}\text { Daya Tanggap } \\
\text { (Responveness) }\end{array}$} & B1 & $\begin{array}{l}\text { Ketanggapan karyawan dalam memilih menu } \\
\text { di Warung Steak On You }\end{array}$ \\
\hline & & B2 & Kesediaan menjawab pertanyaan konsumen \\
\hline & & B3 & $\begin{array}{l}\text { Karyawan segera meminta maaf jika ada } \\
\text { kesalahan atau lama pengantaran makanan }\end{array}$ \\
\hline & & B4 & $\begin{array}{l}\text { Ketersediaan mengarahkan langkah-langkah } \\
\text { sebelum memasuki area tempat makan }\end{array}$ \\
\hline & & B5 & $\begin{array}{l}\text { Karyawan selalu menjaga kelengkapan meja } \\
\text { makan seperti saus, tissue dan lada }\end{array}$ \\
\hline \multirow{5}{*}{3} & \multirow{5}{*}{$\begin{array}{l}\text { Jaminan } \\
\text { (Assurance) }\end{array}$} & $\mathrm{C} 1$ & $\begin{array}{l}\text { Pengetahuan karyawan terhadap menu yang } \\
\text { ada di Warung Steak On You }\end{array}$ \\
\hline & & $\mathrm{C} 2$ & $\begin{array}{l}\text { Kualitas menu yang disediakan sesuai dengan } \\
\text { harga yang ditetapkan }\end{array}$ \\
\hline & & $\mathrm{C} 3$ & $\begin{array}{l}\text { Perasaan aman dan nyaman saat makan di } \\
\text { Warung Steak On You }\end{array}$ \\
\hline & & $\mathrm{C} 4$ & $\begin{array}{l}\text { Perasaan puas konsumen setelah makan di } \\
\text { Warung Steak On You }\end{array}$ \\
\hline & & $\mathrm{C} 5$ & $\begin{array}{l}\text { Kualitas karyawan dengan pelayanan yang } \\
\text { diberikannya }\end{array}$ \\
\hline
\end{tabular}


Kesopanan dan keramahan karyawan atau

D1 pihak warung Steak On You

Sambutan yang diberikan karyawan kepada

D2 konsumen yang baru datang

$4 \quad \begin{aligned} & \text { Empati } \\ & \text { (Empathy) }\end{aligned}$

Mampu berkomunikasi dengan baik terhadap

D3 konsumen

Nada intonasi yang dilafalkan oleh karyawan

D4 kepada konsumennya

Karyawan memahami kondisi dan keadaan

D5 terhadap kebutuhan konsumen

E1 Kenyamanan fasilitas yang diberikan

E2 Kebersihan ruangan dan tempat makan

E3 Jumlah tempat makan yang memadai

$5 \quad$ Bukti Fisik

(Tangible)

E4 Kerapihan pakaian yang digunakan karyawan

Fasilitas pendukung (Toilet, Tempat Sholat

E5 dan Westafel)

Tabel 3. Rekap Per Atribut Persepsi

Tabel 4 Rekap Per Atribut Harapan

\begin{tabular}{|c|c|c|c|c|c|c|c|c|c|}
\hline Atribut & $\mathrm{TP}$ & $\mathrm{CP}$ & $\mathrm{P}$ & SP & Atribut & $\mathrm{TP}$ & $\mathrm{CP}$ & $\mathrm{P}$ & SP \\
\hline A1 & 0 & 2 & 3 & 45 & A1 & 0 & 0 & 5 & 45 \\
\hline $\mathrm{A} 2$ & 0 & 3 & 4 & 43 & A2 & 0 & 0 & 4 & 46 \\
\hline A3 & 10 & 36 & 2 & 2 & A3 & 0 & 0 & 1 & 49 \\
\hline A4 & 38 & 10 & 1 & 1 & A4 & 0 & 1 & 1 & 48 \\
\hline A5 & 0 & 0 & 10 & 40 & A5 & 0 & 0 & 10 & 40 \\
\hline B1 & 0 & 5 & 37 & 8 & B1 & 0 & 0 & 5 & 45 \\
\hline B2 & 2 & 8 & 35 & 5 & B2 & 0 & 0 & 2 & 48 \\
\hline B3 & 38 & 8 & 2 & 2 & B3 & 0 & 5 & 5 & 40 \\
\hline B4 & 2 & 3 & 40 & 5 & B4 & 0 & 2 & 8 & 40 \\
\hline B5 & 0 & 38 & 12 & 0 & B5 & 0 & 3 & 5 & 42 \\
\hline $\mathrm{C} 1$ & 0 & 15 & 40 & 5 & $\mathrm{C} 1$ & 0 & 0 & 2 & 48 \\
\hline $\mathrm{C} 2$ & 0 & 0 & 5 & 45 & $\mathrm{C} 2$ & 0 & 0 & 1 & 49 \\
\hline C3 & 0 & 0 & 7 & 43 & $\mathrm{C} 3$ & 0 & 2 & 3 & 45 \\
\hline $\mathrm{C} 4$ & 0 & 35 & 10 & 5 & $\mathrm{C} 4$ & 0 & 0 & 2 & 48 \\
\hline C5 & 0 & 38 & 12 & 0 & C5 & 0 & 0 & 0 & 50 \\
\hline D1 & 0 & 0 & 42 & 8 & D1 & 0 & 0 & 2 & 48 \\
\hline D2 & 0 & 38 & 10 & 2 & D2 & 0 & 2 & 8 & 40 \\
\hline D3 & 0 & 26 & 16 & 8 & D3 & 0 & 2 & 5 & 43 \\
\hline D4 & 0 & 0 & 30 & 20 & D4 & 0 & 3 & 3 & 46 \\
\hline D5 & 5 & 32 & 8 & 5 & D5 & 2 & 3 & 10 & 35 \\
\hline E1 & 0 & 0 & 5 & 45 & E1 & 0 & 0 & 4 & 46 \\
\hline E2 & 0 & 5 & 40 & 5 & E2 & 0 & 0 & 1 & 49 \\
\hline E3 & 1 & 8 & 40 & 1 & E3 & 0 & 2 & 4 & 44 \\
\hline E4 & 35 & 10 & 3 & 2 & E4 & 0 & 4 & 16 & 30 \\
\hline
\end{tabular}


Siti Nur Khoiria \& Kasful Anwar US, 2021

\begin{tabular}{llllllllll}
\hline E5 & 3 & 8 & 38 & 1 & E5 & 0 & 5 & 10 & 35
\end{tabular}

Tabel 5. Hitung Rekap Per Atribut

\begin{tabular}{|c|c|c|c|c|c|}
\hline Atribut & $\begin{array}{l}\text { Nilai Bobot } \\
\text { Persepsi }\end{array}$ & $\begin{array}{l}\text { Nilai Bobot } \\
\text { Harapan }\end{array}$ & $\begin{array}{l}\text { Rata-Rata } \\
\text { Persepsi }\end{array}$ & $\begin{array}{l}\text { Rata-Rata } \\
\text { Harapan }\end{array}$ & $\begin{array}{l}\text { Nilai GAP } \\
(\mathrm{G}=\mathrm{P}-\mathrm{E})\end{array}$ \\
\hline A1 & 193 & 195 & 3,86 & 3,9 & $-0,04$ \\
\hline $\mathrm{A} 2$ & 190 & 196 & 3,8 & 3,92 & $-0,12$ \\
\hline $\mathrm{A} 3$ & 96 & 199 & 1,95 & 3,98 & $-2,03$ \\
\hline $\mathrm{A} 4$ & 65 & 197 & 1,3 & 3,94 & $-2,64$ \\
\hline A5 & 190 & 190 & 3,8 & 3,8 & 0 \\
\hline B1 & 153 & 195 & 3,06 & 3,9 & $-0,84$ \\
\hline B2 & 143 & 198 & 2,86 & 3,96 & $-1,1$ \\
\hline B3 & 68 & 185 & 1,36 & 3,7 & $-2,34$ \\
\hline B4 & 148 & 188 & 2,96 & 3,76 & $-1,07$ \\
\hline B5 & 112 & 189 & 2,24 & 3,78 & $-1,54$ \\
\hline $\mathrm{C} 1$ & 170 & 198 & 3,4 & 3,96 & $-0,56$ \\
\hline $\mathrm{C} 2$ & 195 & 199 & 3,9 & 3,98 & $-0,08$ \\
\hline $\mathrm{C} 3$ & 193 & 193 & 3,86 & 3,86 & 0 \\
\hline $\mathrm{C} 4$ & 120 & 198 & 2,4 & 3,96 & $-1,56$ \\
\hline $\mathrm{C} 5$ & 112 & 200 & 2,24 & 4 & $-1,76$ \\
\hline D1 & 158 & 198 & 3,16 & 3,96 & $-0,8$ \\
\hline D2 & 114 & 190 & 2,28 & 3,8 & $-1,52$ \\
\hline D3 & 132 & 191 & 2,64 & 3,82 & $-1,18$ \\
\hline D4 & 170 & 199 & 3,4 & 3,98 & $-0,58$ \\
\hline D5 & 113 & 178 & 2,26 & 3,56 & $-1,3$ \\
\hline E1 & 195 & 196 & 3,9 & 3,92 & $-0,02$ \\
\hline E2 & 132 & 199 & 2,64 & 3,98 & $-1,34$ \\
\hline E3 & 141 & 194 & 2,82 & 3,88 & $-1,06$ \\
\hline E4 & 72 & 176 & 1,44 & 3,52 & $-2,08$ \\
\hline E5 & 137 & 180 & 2,74 & 3,6 & $-0,86$ \\
\hline
\end{tabular}

Tabel 6. Hitung Rekap Per Dimensi

\begin{tabular}{llllll}
\hline Dimensi & $\begin{array}{l}\text { Nilai } \\
\text { Persepsi }\end{array}$ & $\begin{array}{l}\text { Nilai } \\
\text { Harapan }\end{array}$ & $\begin{array}{l}\text { Rata- } \\
\text { Rata } \\
\text { Persepsi }\end{array}$ & $\begin{array}{l}\text { Rata- } \\
\text { Rata } \\
\text { Harapan }\end{array}$ & $\begin{array}{l}\text { GAP } \\
\text { Ke-5 } \\
\text { Dimensi }\end{array}$ \\
\hline $\begin{array}{l}\text { Kehandalan } \\
\text { Reliability) }\end{array}$ & 14,71 & 19,54 & 2,94 & 3,91 & $-0,97$ \\
$\begin{array}{l}\text { Daya Tanggap } \\
\text { (Responsiveness) }\end{array}$ & 12,48 & 19,1 & 2,50 & 3,82 & $-1,32$ \\
$\begin{array}{l}\text { Jaminan } \\
\text { (Assurance) }\end{array}$ & 15,8 & 19,76 & 3,16 & 3,96 & $-0,8$ \\
$\begin{array}{l}\text { Empati } \\
\text { (Empathy) }\end{array}$ & 13,74 & 19,12 & 2,75 & 3,82 & $-1,07$ \\
$\begin{array}{l}\text { Bukti Fisik } \\
\text { (Tangible) }\end{array}$ & 13,54 & 18,9 & 2,71 & 3,78 & $-1,07$ \\
\hline
\end{tabular}


Dari penelitian ServQual diatas peneliti mendapatkan hasil bahwa

- Nilai GAP Terkecil dengan kinerja yang perlu dipertahankan terletak pada Dimensi Jaminan (Reliability)

- Nilai GAP Terbesar dengan kinerja yang perlu ditingkatkan terletak pada Dimensi Daya Tanggap (Responsiveness)

\section{Analisis Deskriptif}

Pada bagian ini akan dilakukan analisis berupa seberapa besar harapan dan persepsi konsumen terhadap kualitas pelayanan yang ada Di Warung Steak On You Kota Baru Jambi setelah dilakukan pengumpulan data oleh peneliti. Maka peneliti mendapatkan hasil sebagai berikut:

a) Dimensi Reliability (Kehandalan)

Dari data yang didapatkan oleh peneliti pihak perusahaan harus meningkatkan lagi kinerja nya dalam dimensi ini karena dari beberapa konsumen mengatakan masih menunggu waktu yang lama untuk penyajian makanannya. Dan mungkin hal ini juga disebabkan beberapa faktor yaitu karena banyaknya konsumen yang datang dan memesan makanan ataupun minuman yang sama dengan konsumen lainnya jadi proses penyajian makanannya membutuhkan estimasi waktu yang lama. Lalu karena faktor SDA nya yang masih kurang, jumlah karyawan yang tidak memadai atau mungkin bisa juga disebabkan karyawan yang bertugas didapur juga sedikit.

b) Dimensi Responsiveness (ketanggapan)

Pada dimensi ini peneliti mendapatkan hasil bahwa para karyawan dinilai kurang memberikan kualitas pelayanannya karena kurangnya daya tanggap yang karyawan miliki. Untuk ketersediaan dimeja makan seperti saus, tissue dan lada juga kurang diperhatikan oleh pihak karyawan. Hal itu yang membuat konsumen 1 harus meminta kepada konsumen sebelahnya untuk memenuhi ketersediaan yang ada diatas meja makan. Pada dimensi ini Warung Steak On You sangat memberikan pelayanan yang terbaik. Sebelum pandemic Covid-19 saat ini yang biasanya Warung Steak On You membiarkan konsumennya untuk mencatat sendiri tetapi karena saat pandemic Covid-19 saat ini para karyawannya langsung yang mencatat pesanan konsumen. Para karyawan juga dinilai kurang cepat tanggap untuk mengarahkan konsumen kea rah meja makan. Maka dari itu diperlukannya peningkatan kualitas pelayanan dari karyawan untuk dimensi ini dan lebih ditingkatkan lagi daya tanggap serta kesediaan para karyawan.

c) Dimensi Assurance (Jaminan)

Peneliti mendapatkan hasil bahwa para konsumen merasa puas dengan harga dan produk yang diberikan oleh Warung Steak On You dengan makanannya yang lezat dan dengan harga yang pas dikantong. Apalagi sebagian besar sampel dari penelitian ini adalah anakanak remaja yang masih sekolah dan anak kuliahan yang sebagian masih mendapatkan uang saku dari orang tuanya. Konsumen juga merasa puas dengan pelayanan fasilitas yang diberikan mulai dari tempat dan suasana yang aman dan nyaman ditambah dengan alunan musik yang diputar yang membuat konsumen merasa tenang makan di Warung Steak On You. Konsumen juga berharap pada dimensi ini untuk dipertahankan jaminan yang diberikan oleh Warung Steak On You.

d) Dimensi Empathy (Empati)

Pada dimensi ini peneliti mendapatkan data bahwa para karyawan melayani para 
konsumennya dengan sangat ramah dan baik. Bahasa yang mudah dipahami dan kesopanan yang diberikan karyawan juga baik. Ada juga yang mengatakan pelayanan yang diberikan kasir juga ramah. Lalu ada beberapa konsumen wanita yang merasa risih dan sedikit terganggu dengan pelayanan yang diberikan oleh karyawannya karena kebanyakan karyawan di Warung Steak On You ini adalah laki-laki. Jadi beberapa konsumen juga berharap agar karyawannya juga lebih menjaga etika dan kesopanan terhadap konsumen wanitanya.

e) Dimensi Tangible (Bukti Fisik)

Tempat dan ruangan yang diberikan juga sangat nyaman dan bersih. Dibalut dengan dekorasi dan design ruangan yang menambah nilai estetika dari Warung Steak On You ini. Serta disertai dengan fasilitas pendukung seperti wastafel untuk tempat cuci tangan sebelum memasuki area makan dan pastinya ini sudah menjadi tingkat kebersihan konsumen sebelum makan. Lalu Warung Steak On You ini juga menyediakan fasilitias lain seperti WC dan tempat sholat. Jadi konsumen juga merasa puas untuk bukti fisik yang diberikan oleh Warung Steak On You ini. Konsumen juga berharap agar Warung Steak On You ini tetap mempertahankan kualitas dimensi ini.

\section{Kualitas Pelayanan Mempunyai Pengaruh Yang Positif Terhadap Kepuasan Konsumen}

Hasil dari penelitian menggunakan metode SERVEQUAL dan analisis deskriftif kualitatif bahwa secara keseluruhan kualitas yang diberikan oleh Warung Steak On You baik itu dari karyawannya ataupun pihak Warung nya langsung mempunyai pengaruh yang sangat signifikan terhadap kepuasan konsumen. Dan kualitas pelayanan ini juga memberikan pengaruh yang positif bagi konsumennya langsung jika para konsumen merasa puas mereka bisa saja kembali lagi ke Warung Steak On You untuk menjadi pelanggan dan bisa saja konsumen itu mengajak konsumen lainnya untuk makan di Warung Steak On You karena pihak Warung memberikan kualitas pelayanan yang baik tetapi bukan hanya dari segi pelayannya saja tetapi juga bisa dari segi makanan dan harganya langsung.

\section{KESIMPULAN}

Berdasarkan hasil dari penelitian tentang Analisis Kepuasan Konsumen Terhadap Kualitas Pelayanan Warung Steak On You Kota Baru Jambi dengan menggunakan metode ini dapat disimpulkan bahwa tingkat pelayanan yang diberikan oleh Warung Steak On You sangatlah berpengaruh terhadap kepuasan konsumen dan sebaiknya jug ajika ada kekurangan dari pelayanan yang diberikan bisa diperbaiki lagi. Guna mencapai tingkat kepuasan konsumen kedepannya untuk mencapai hasil yang memuaskan bagi Warung Steak On You itu sendiri.

\section{DAFTAR PUSTAKA}

Farah, Silcyljeova \& Imelda. 2016. Pengaruh Kualitas Pelayanan, Kualitas Produk Dan Kepercayaan Terhadap Kepuasan Konsumen (Studi Pada PT. Fifgroup Cabang Manado). Journal Of EMBA (1) 109-119

Heriyanto, Prabowo. 2013. Analisis Pemanfaatan Buku Elektronik (E-Book) Oleh Pemustaka Di Perpustakaan Sma Negeri 1 Semarang. Journal of Library Science (2) $1-9$ 
Hestanto. 2020. Manfaat dan Strategi Kepuasan Pelanggan. [Internet]. [diakses 22 April 2021]. Tersedia pada https://www.hestanto.web.id/manfaat-dan-strategikepuasanpelanggan/

Indrasari. 2019. Pemasaran dan Kepuasan Pelanggan. Jawa Timur: Unitomo Press.

Jackson, Musselman. 1988. Pengantar Ekonomi Perusahaan. Jakarta: Erlangga.

J Lee, Martyn. 2006. Budaya Konsumen Terlahir Kembali. Yogyakarta: Kreasi Wacana Yogyakarta.

Moenir. 2006. Manajemen Pelayanan Umum Di Indonesia. Jakarta: Bumi Aksara.

Purwono, Hidayat. 2016. Studi Kelayakan Bisnis. Jakarta: Rajawali Pers.

Sugi Priharto. 2020. Indikator Kepuasan Pelanggan: Pengertian, Jenis, dan Fungsinya Bagi

Bisnis. [Internet]. [diakses 22 April 2021]. Tersedia pada

https://accurate.id/marketingmanajemen/indikator-kepuasan-pelanggan/

Sumarwan. 2003. Perilaku Konsumen (Teori dan Penerapannya Dalam Pemasaran). Jakarta: Ghalia Indonesia.

Situmorang, Ira, Nasari\& Fina. 2019. Analisis Kepuasan Konsumen Terhadap Layanan SPA Dengan SERVQUAL (Studi Kasus: PT. Royal Amadeus). Journal Of Information Systems And Information Technology 521-528

Suandi. 2019. Analisis Kepuasan Masyarakat Terhadap Pelayanan Publik Berdasarkan Indeks Kepuasan Masyarakat Di Kantor Kecamatan Belitang Kabupaten Oku Timur. Journal of Administrative Sciences and Policy Studies (1) 13-22

Tika. 2006. Budaya Organisasi dan Peningkatan Kinerja Perusahaan. Jakarta: Bumi Aksara. 